\title{
Milankovitch cycles and microfossils: principles and practice of palaeoecological analysis illustrated by Cenomanian chalk-marl Rhythms
}

\author{
C.R. PAUL \\ Department of Earth Sciences \\ Liverpool University, \\ Liverpool L69 3BX, UK
}

\begin{abstract}
While standardization of sampling, processing and picking techniques is essential in micropalaeontology, standard counts (and percentages) have three serious disadvantages. They are interdependent, so changes in one taxon affect counts of all others; they can be misleading, e.g. when percentage abundance increases but absolute numbers decrease; and they conceal changes in absolute abundance, which for palaeoecology are often most revealing. A technique which combines a minimum count with estimates of absolute numbers is recommended and has been applied to 12 samples from a mid-Cenomanian chalk/marl rhythm. Data for insoluble residues, stable isotopes of carbon and oxygen and numbers of planktonic and benthonic foraminifera and ostracods all vary through the rhythm. Absolute abundance of planktonic foraminifera correlates best with surface sea water temperatures calculated from oxygen isotopes. Abundances of both calcareous and agglutinated benthonic foraminifera correlate best with percent insoluble residue values and these foraminifera respond passively to changes in sedimentation rate. Ostracods do not correlate well with either control. Ratios of insoluble residues and of benthonic foraminiferal abundances between chalks and marls confirm that the rhythms are productivity cycles. Mid-Cenomanian chalk beds were deposited rapidly, taking at most 5-7000 years of the 21,000 year precession cycle. J. Micropalaeontol. 11(1), 95-105, June 1992.
\end{abstract}

\section{INTRODUCTION}

The idea that secular variations in properties of the earth's orbit may control climatic cycles (Milankovitch cycles) has a long history (Croll, 1875) and is now well established (Shackleton \& Opdyke, 1973). Equally, the idea that rhythmic sediments may reflect Milankovitch cycles is scarcely new (Gilbert, 1895). The connecting link, that is by what mechanisms do Milankovitch cycles produce rhythmic sediments, is still not well understood. It is unlikely that a single mechanism will be found to predominate. Lower Liassic rhythms in Britain show, inter alia, clear evidence for fluctuations from anoxic bottom conditions represented by laminated black shales, to more oxygenated and calcareous marls and limestones which often contain a good benthonic macrofauna, whereas there is no evidence at all for anoxia in the Cenomanian chalk/marl rhythms which form the subject of this paper. Ditchfield \& Marshall (1989) presented oxygen isotope data for three Cenomanian rhythms which showed the chalks to have been formed in surface sea water about $2^{\circ} \mathrm{C}$ warmer than the marls. The chalk beds seem to be productivity events caused by repeated coccolith blooms in warmer sea water. If this is so, it is puzzling that foraminifera are more abundant in the marls than in the chalks (Leary \& Ditchfield, 1989), which leads to the second aspect of this paper. The common micropalaeontological practice of making standard fixed counts, largely developed for biostratigraphic purposes, obscures data on abundance and is less suitable for palaeoecology. Thus the two aims of this paper are to discuss the micropalaeontological evidence for the generation of Cenomanian chalk/marl rhythms, and the best ways of gathering and presenting this evidence. Since the techniques used here diverge somewhat from standard practice, they are described in detail below.

\section{MATERIALS AND METHODS}

\section{a) Field}

Samples of about $500 \mathrm{~g}$ weight were collected from a column section at $6 \mathrm{~cm}$ intervals throughout the rhythm, which is from the third to the fourth chalk beds above the mid-Cenomanian non-sequence in a section at Abbot's Cliff, between Dover and Folkestone, Kent (National Grid Reference TR277387; Fig. 1). Samples were numbered from 1 (base) to 12 .

\section{b) Laboratory}

Subsamples of approximately $100 \mathrm{~g}$ were used for micropalaeontology. They were dried, weighed, and dissociated by repeated freezing and thawing in water. The method is cheap, fairly effective if rather slow, and causes minimal damage to microfossils. Chalk samples proved less susceptible to breakdown than marls. To minimize variations introduced by more intensive treatment of some samples, all samples were wet sieved through a $63 \mu \mathrm{m}$ mesh after a similar, but not identical, number of freeze/thaw cycles. Residues were separated by filtration, dried, weighed and size sorted using a nest of sieves at 1 phi intervals from $4 \mathrm{~mm}$ to $63 \mu \mathrm{m}$ mesh. Residue greater than $1 \mathrm{~mm}$ was regarded as unprocessed, and its weight recorded and deducted from the original sample weight to give an effective sample weight. The latter was used in all calculations of absolute abundance. 


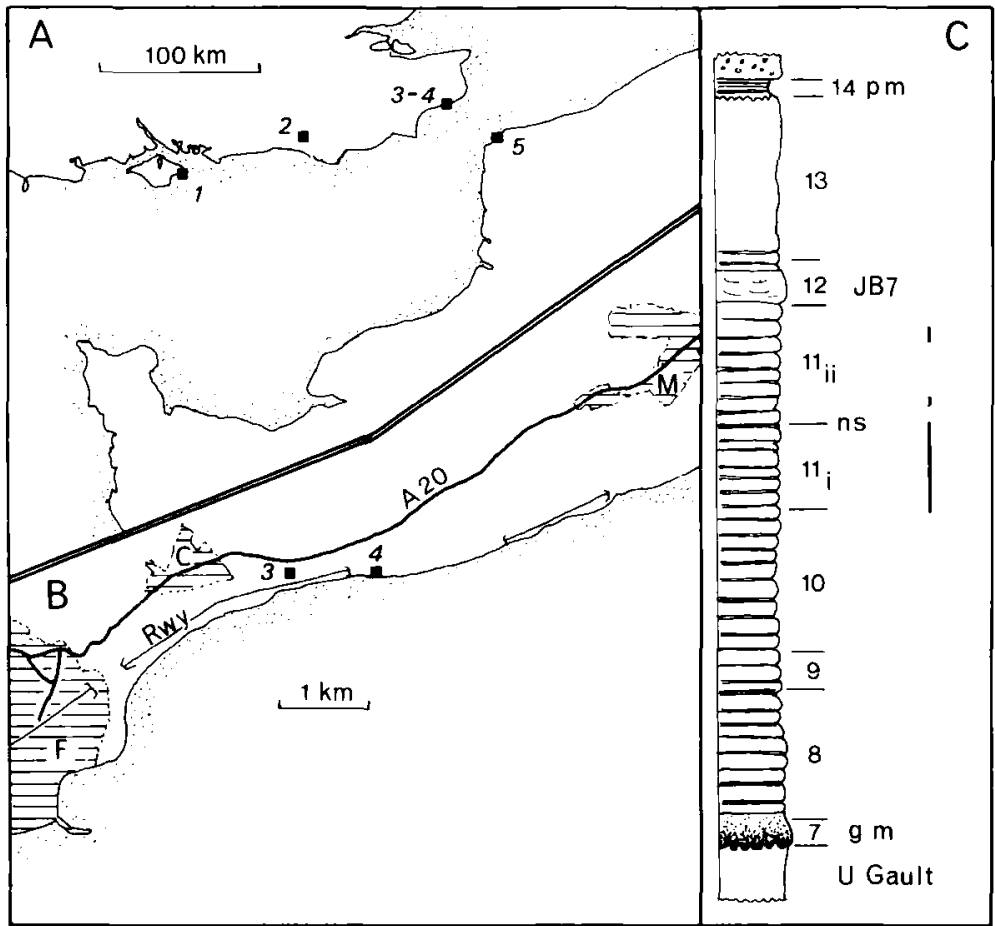

Fig. 1A, B. Locations of sections discussed in the text. 1. Culver Cliff, Isle of Wight; 2. Southerham, Sussex; 3 . The Warren, Folkestone, Kent; 4. Abbot's Cliff, Kent; 5. Cap Blanc Nez, France. C Capel-le Ferne; M Maxton (a suburb of Dover); Rwy railway.

Fig.1C Schematic section through the Cenomanian succession between Folkestone and Dover (after Carter \& Hart, 1977, Fig.17) to show positions of sections discussed in the text. 7-14 Carter \& Hart's (1977) benthonic foraminiferan zones; gm Glauconitic Marl; ns mid-Cenomanian non-sequence; JB7 Jukes Browne's bed 7, (Jukes-Browne \& Hill, 1903, pp. 37, 41); pm Plenus Marls. Upper section data from locality 3 , middle section from locality 4 , lower section (insoluble residues only) from localities 1-2, 4-5.

Residues were picked under a Kyowa binocular microscope using an aluminium picking tray with 49 scored rectangles, and foraminifera and ostracods mounted on faunal mount slides. All the $500 \mu \mathrm{m}$ fraction was picked and used to predict the likely total number of foraminifera in the $250 \mu \mathrm{m}$ fraction. This estimate was then used to determine the number of individual rectangles in the picking tray which needed to be picked entirely to yield a total of at least 250 individual foraminifera. The number varied from 3 to 20, and estimates of the total numbers of both foraminifera and ostracod valves were calculated by multiplying by the appropriate factor. $95 \%$ confidence intervals on estimates of total foraminifera were calculated using the formula given by Mosimann (1965, p.659). Numbers of ostracods were toosmall to give reliableconfidence intervals in some samples so none is presented here). Residue was scattered as evenly as possible across the picking tray and different rectangles picked from each scattering in an attempt to eliminate systematic errors introduced by uneven scatter. The estimates of total numbers were then corrected by the effective sample weight to yield a final figure of estimated total specimens per $100 \mathrm{~g}$ of original sediment.
Additional small subsamples of a few grammes were ground to powder in a pestle and mortar and used for insoluble residue determinations and stable isotope analysis. Insoluble residues were determined by dissolving approximately $0.1 \mathrm{~g}$ powder in excess $10 \% \mathrm{HCl}$, filtering, washing and weighing the residue. Powders were analysed for stable isotopes of carbon and oxygen in the University of Liverpool Stable Isotope Laboratory. All samples were roasted in a low pressure plasma oven for four hours to remove any organic matter. Gaseous $\mathrm{CO}_{2}$ for analysis was released by reacting $3 \mathrm{mg}$ samples with $2 \mathrm{ml}$ of anhydrous $100 \%$ orthophosphoric acid at $25^{\circ} \mathrm{C}$ in a constant temperature bath until the reaction was complete or for at least two hours. An acid fractionation factor of 1.01025 was used (Friedman \& $\mathrm{O}^{\prime} \mathrm{Neal}, 1977$ ). Results were corrected by standard methods (Craig, 1957) and are expressed as per mil (\%) deviation from the Pee Dee Belemnite (PDB) international standard.

Foraminifera and ostracods were identified to genera and a data matrix of estimated total numbers per $100 \mathrm{~g}$ sample for each genus constructed. Selected results are presented graphically below, but the entire data set is available on request. Faunal mounts and remaining residues have been deposited in Liverpool Museum (LIVCM).

\section{DISCUSSION OF METHODS}

Standard micropalaeontological techniques have been developed largely in response to biostratigraphic needs, which do not necessarily coincide with those of palaeoecological analysis. One clear requirement in biostratigraphy is equally thorough treatment of samples. The practice of making standard counts has developed largely, I suspect, to ensure that key taxa are not overlooked. (See the discussion in Shaw, 1964, p.107 et seq.). For example with 299 and 459 identified specimens, one can be $95 \%$ and $99 \%$ certain, respectively, of not overlooking a taxon present as $1 \%$ of the sample. (See tables in Shaw, 1964, p.109; Paul, 1982, p.86; and graph in Hay, 1972, p.259).

\section{a) Problems with standard counts}

Admirable as standard counts are for biostratigraphy, they suffer from three grave disadvantages when applied to palaeoecology. Making absolute or standard counts and expressing the results as percentages has the same effect. All the disadvantages of standard counts apply to percentages. They are, in effect, standard counts of 100.

First standard counts or percentages for all taxa are interdependent. If one changes value, all the others must change in response. This effect is most marked when the commonest taxa fluctuate in abundance, but it is always present. In palaeoecology it is important to separate signal (i.e. a genuine change in the abundance of a taxon) from echo (i.e. a passive response to a change in the abundance of another taxon), especially if the ecological requirements of the taxa are known and used in the interpretation of the results. However, 
in biostratigraphy it doesn't matter what generates the pattern if it can be used successfully for correlation. Indeed, a method which exaggerates the pattern by adding echo to signal, may actually be preferable. Fig. 2 represents pure echo. It was constructed on the assumption that the taxon concerned was present at an absolutely invariant abundance in terms of specimens per square metre of sea floor or per gramme of sediment. The pattern is purely a passive response to fluctuations at different frequencies in two other common taxa. Although Murray $(1973$, p.1) has made this point in a different manner, its consequences do not seem to be generally appreciated.

Secondly, standard counts and percentages may give misleading impressions and suggest inappropriate conclusions. For example, Leary et al. (1989, pp.417-8) present data for percentage abundance of Hedbergella and Gavelinella through three Cenomanian chalk/marl rhythms. Both genera are proportionately more abundant in the chalks than the marls (Table 1), which suggests that they were better adapted to the conditions that induced chalk, rather than marl, deposition. However, absolute abundances per $500 \mathrm{~g}$ show the reverse (Table 2), which suggests that the two genera were tolerant forms, less seriously affected by the conditions resulting in chalk sedimentation than other taxa.

Finally, of course, standard counts and percentages completely obscure data on absolute abundance, not only between samples from the same rhythm but also from rhythm to rhythm. In the examplequoted above Leary found densities of 0.515-1.626 foraminifera per $\mathrm{g}$ from the 500 and $250 \mu \mathrm{m}$ fractions combined, whereas I have densities of 6.31-74.34 specimens per $\mathrm{g}$ from the $250 \mu \mathrm{m}$ fraction alone. Neither Paul Leary nor I can explain this amazing discrepancy, but suffice it to say standard counts or percentages would completely obscure these differences, let alone any variation in abundance within the same rhythm. Even the latter can be quite significant. In the data presented here there is more than an order of magnitude difference in total numbers of foraminifera between the richest and most barren samples. Very few species will have standard counts or pecentages that vary by this much.

Nevertheless, any quantitative data do need to be based on adequate counts. The procedure adopted here was to develop a technique which combines an adequate count with evidence of total numbers. The 500 and $250 \mu \mathrm{m}$ fractions from the sample with the most meagre fauna (sample 12) were picked completely. Part way through picking the $250 \mu \mathrm{m}$ fraction the picked and unpicked portions were weighed and the ratio of weights used to predict the total numbers present. This underestimated the actual total numbers of foraminifera and ostracods by 18 and $12 \%$, respectively, a not unexpected result since even within one size fraction scattering subsamples on a picking tray tends to sort residue by size with larger particles

\begin{tabular}{lcc}
\cline { 2 - 2 } & Gavelinella & Hedbergella \\
Chalk $(\mathrm{n}=15)$ & 42.64 & benthonic fauna) \\
Marl $(\mathrm{n}=10)$ & 35.73 & 44.56 \\
\end{tabular}

Table 1. Mean percentage abundance of Gavelinella and Hedbergella from chalk and marl beds in three Cenomanian rhythms.

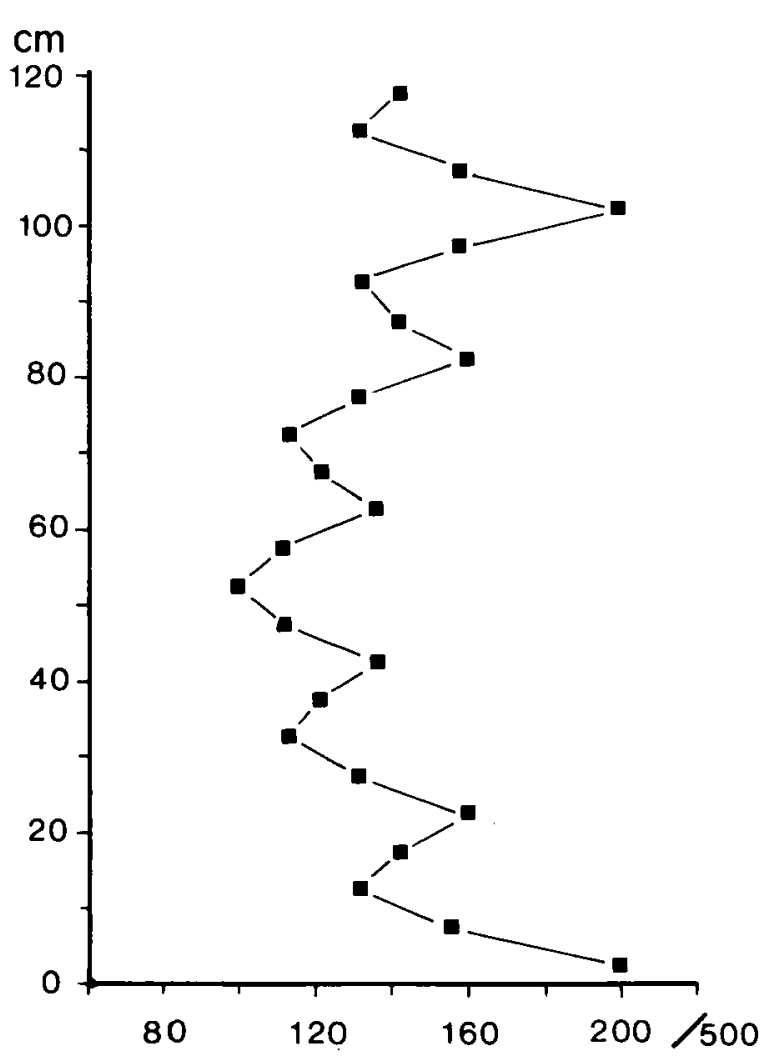

Fig. 2 Artificial pattern (echo) in apparent abundance of one taxon generated by making fixed counts of 500 specimens in samples in which there are variations in the abundances of two other common taxa. By definition this taxon did not vary in abundance whatsoever. See text for further explanation.

emerging first. Thus later scatterings are often richer in specimens. In this case nearly two thirds of the sample had already been picked when the weighing was undertaken, so this effect is not negligible. As a result, an alternative strategy of picking only specimens which fell within a fixed number of rectangles on the picking tray was adopted. This avoids the effects of size sorting and variations in density of each scattering, while varying the precise rectangles picked with each scattering avoids systematic errors introduced by uneven scattering.

For each subsequent sample, the $500 \mu \mathrm{m}$ fraction was picked entirely, the total number of foraminifera and ostracod valves combined was used to predict likely total numbers of foraminifera in the $250 \mu \mathrm{m}$ fraction. (Empirically, it was found that the ratio of total numbers of specimens in the $500 \mu \mathrm{m}$ fraction to total foraminifera in the $250 \mu \mathrm{m}$ fraction was about 1:30). This prediction was then used to calculate the minimum number of rectangles necessary to yield at least 250

\begin{tabular}{lccc}
\hline & Gavelinella & Hedbergella \\
Chalk $(\mathrm{n}=15)$ & 90 & & 177 \\
Marl $(\mathrm{n}=10)$ & 136 & & 230
\end{tabular}

Table 2. Mean absolute abundance (per $500 \mathrm{~g}$ sample) of Gavelinella and Hedbergella from chalk and marl beds in three Cenomanian rhythms 
foraminifera. In practice one or two counts proved low, so additional pickings were undertaken. This resulted in no sample being based on less than 300 actual foraminifera and only two samples had less than 400 . All ostracod valves found in the rectangles were also removed, but generally these were present in much lower numbers.

Once it is decided that total numbers will be estimated, equally thorough processing becomes essential. Clearly estimated total numbers must be based on a fixed weight of thoroughly processed sediment, whereas for standard counts it is only necessary for enough of the sample to break down to yield an adequate number of specimens. The proportion of the original rock which is effectively processed is irrelevant. Three of the samples discussed here resisted dissociation significantly. To avoid the danger of bias introduced by changing the processing technique, or by more severe application of the same technique, the freeze/thaw cycle applied to thesesamples was stopped well short of total breakdown. For all samples, the $1 \mathrm{~mm}$ and coarser fractions were regarded as unprocessed, weighed, and the weight deducted from the original sample weight togive an effective weight processed. These last figures were used in the estimates of absolute abundance expressed as specimens per $100 \mathrm{~g}$.

\section{b) Problems induced by size variation}

As any micropalaeontologist is aware the proportions of different taxa vary in different size fractions of the same sample. Thus combining data from more than one size fraction introduces two elements of variation. The first is genuine fluctuations in abundance of taxa, and the second is variation in the contributions of each size fraction to the standard count. This is best illustrated by considering the planktonic/benthonic $(\mathrm{P} / \mathrm{B})$ ratio because it is an extreme and obvious case. Planktonic foraminifera rarely occur in the $500 \mu \mathrm{m}$ fraction and some forms (e.g. Heterohelicidae and Planomalinidae) do not even occur in the $250 \mu \mathrm{m}$ fraction. Thus the $\mathrm{P} / \mathrm{B}$ ratio is particularly susceptible to spurious variation due to changes in the numbers of foraminifera in the $500 \mu \mathrm{m}$ fraction. Furthermore, standard counts of different sizes made from the sample will give different $P$ / $B$ ratios (Table 3 ). This problem is obvious and in practice $P / B$ ratios are usually calculated from the $250 \mu \mathrm{m}$ fraction only, but all foraminifera are affected in the same way.

In the samples discussed here some genera (e.g. Lenticulina and Tritaxia) vary in size through the rhythm. I have not

Standard count 300

Size fraction $500 \mu \mathrm{m}$

50 $\quad$ Apparent \%

Foram type (all benthonic) (benthonic) (planktonic) planktonic

$\begin{array}{lllll}\text { Sample A } & 100 & 100 & 100 & 33.3 .\end{array}$

$\begin{array}{lllll}\text { Sample B } & 200 & 50 & 50 & 16.7\end{array}$

Standard count 500

$\begin{array}{lllll}\text { Sample A } & 100 & 200 & 200 & 40.0 \\ \text { Sample B } & 200 & 150 & 150 & 30.0\end{array}$

Table 3. Variations in apparent percentage abundance of planktonic foraminifera caused by different contributions of the $500 \mu \mathrm{m}$ fraction and by different standard counts. In both samples the true proportion of planktonic foraminifera is $50 \%$.

$\begin{array}{lcccrl}\begin{array}{l}\text { Stratigraphic } \\ \text { level }(\mathrm{cm})\end{array} & \text { Lenticulina } & \text { Tritaxia } & \begin{array}{c}\text { Pseudo- } \\ \text { textulariella }\end{array} & \begin{array}{c}\text { Areno- } \\ \text { bulimina }\end{array} & \begin{array}{c}\text { Total } \\ \text { fauna }\end{array} \\ 69 & 21.43 & 3.77 & 0 & 7.35 & 4.12 \\ 63 & 10.66 & 0.57 & 0 & 6.91 & 2.06 \\ 57 & 9.61 & 1.01 & 0 & 18.11 & 1.85 \\ 51 & 6.84 & 2.13 & 10.91 & 8.92 & 0.88 \\ 45 & 5.16 & 1.28 & 0 & 10.18 & 0.79 \\ 39 & 10.13 & 1.64 & 100 & 7.08 & 1.32 \\ 33 & 8.41 & 2.60 & 44.94 & 14.58 & 1.93 \\ 27 & 5.09 & 1.91 & 48.42 & 7.28 & 1.72 \\ 21 & 4.80 & 3.42 & 14.41 & 6.11 & 1.13 \\ 15 & 7.67 & 3.03 & 34.23 & 6.67 & 1.28 \\ 9 & 14.53 & 1.56 & 39.26 & 24.42 & 2.28 \\ 3 & 6.27 & 3.61 & 26.98 & 18.27 & 2.05\end{array}$

Table 4. Proportions of specimens (for selected genera and the total fauna) in the $500 \mu \mathrm{m}$ fraction expressed as a percentage of the $500+$ $250 \mu \mathrm{m}$ fractions combined, from a Cenomanian chalk/marl rhythm. Note the fluctuations for individual genera and the small overall proportion of the total fauna.

attempted any thorough analysis of size variation, but as an example mean maximum diameter of the fivelargest examples of Lenticulina in each sample averages $1.046 \mathrm{~mm}$ in the chalks and $1.254 \mathrm{~mm}$ in the marls (Fig. 3). Furthermore, for some taxa the proportion of specimens from the $500 \mu \mathrm{m}$ fraction varies widely (Table 4). Problems induced by size variation are real and so results quoted in this paper are exclusively from the $250 \mu \mathrm{m}$ fraction. This should not cause a significant loss of information as total numbers of specimens from the $500 \mu \mathrm{m}$ fraction only exceed $4 \%$ of the estimated total from the 500 and $250 \mu \mathrm{m}$ fractions combined in one sample and in most they are less than $2 \%$ (Table 4 ).

Finally, in this paper generic diversity has been ignored. First and foremost because it is largely controlled by the almost random occurrence of one or two specimens of several nodosarian genera (Dentalina, Frondicularia, Globulina, Guttulina, Marginulina, Nodosaria, Saracenaria and Vaginulina) which collectively never exceed $5 \%$ of the total fauna and usually only amount to $2-3 \%$. Furthermore, this is quite apart from any problems of generic limits, such as where an evolute Lenticulina becomes a Marginulina or a Saracenaria. Secondly, diversity is related to samplesize but not in an easily predictable way. Since the counts I made vary from 328 to 924 , this will inevitably have some effect on generic diversity. While rarefaction (Raup, 1975) will allow comparisons at equal (the smallest) sample size, it was not deemed worth the effort for what, I suspect, is very small and probably random variation in numbers of nodosarians.

\section{RESULTS}

a) Insoluble residues (Fig. 4A)

Samples were initially identified as either chalk or marl in the field by visual inspection. Percentage insoluble residue values confirm these assignments. Although values range from 8.27 to $22.07 \%$, all marl samples contain more than $18 \%$, and all chalks less than $16 \%$, insoluble residue. Using this cutoff, marls average $19.76 \%$, and chalks $13.08 \%$, insoluble residue. The difference is even more marked using just the complete rhythm, i.e. ignoring the two lowest chalk samples, when chalk averages $12.4 \%$ insoluble content. 

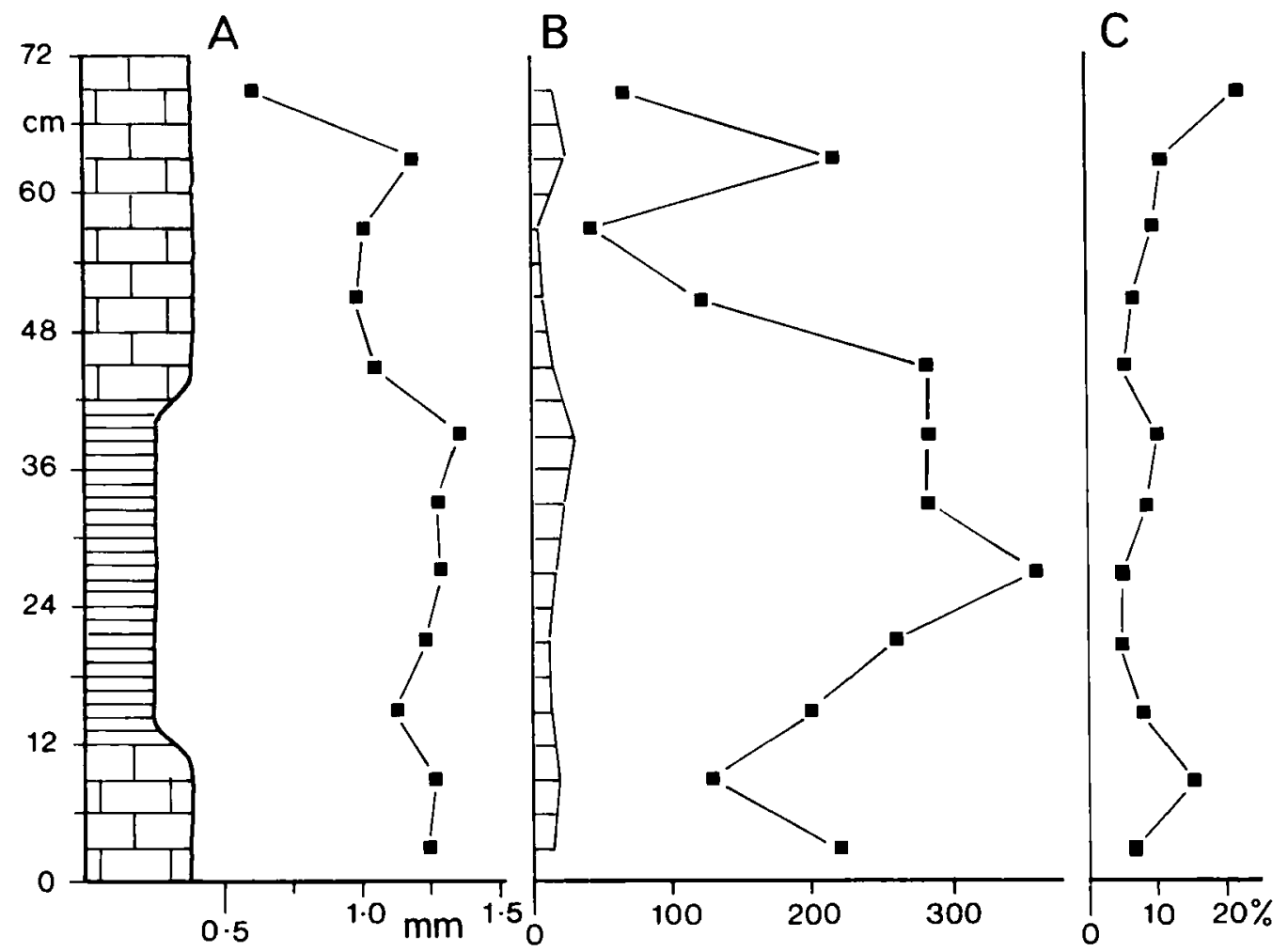

Fig. 3 Variation in Lenticulina through a Cenomanian chalk/marl rhythm. A Mean maximum diameter ( $\mathrm{N}=5) ; \mathrm{B}$ Absolute abundance per 100g of sediment in the $500 \mu \mathrm{m}$ (horizontal shading) and $250 \mu \mathrm{m}$ size fractions; C Numbers in the $500 \mu \mathrm{m}$ fraction as a percentage of the $500+200 \mu \mathrm{m}$ fractions combined.
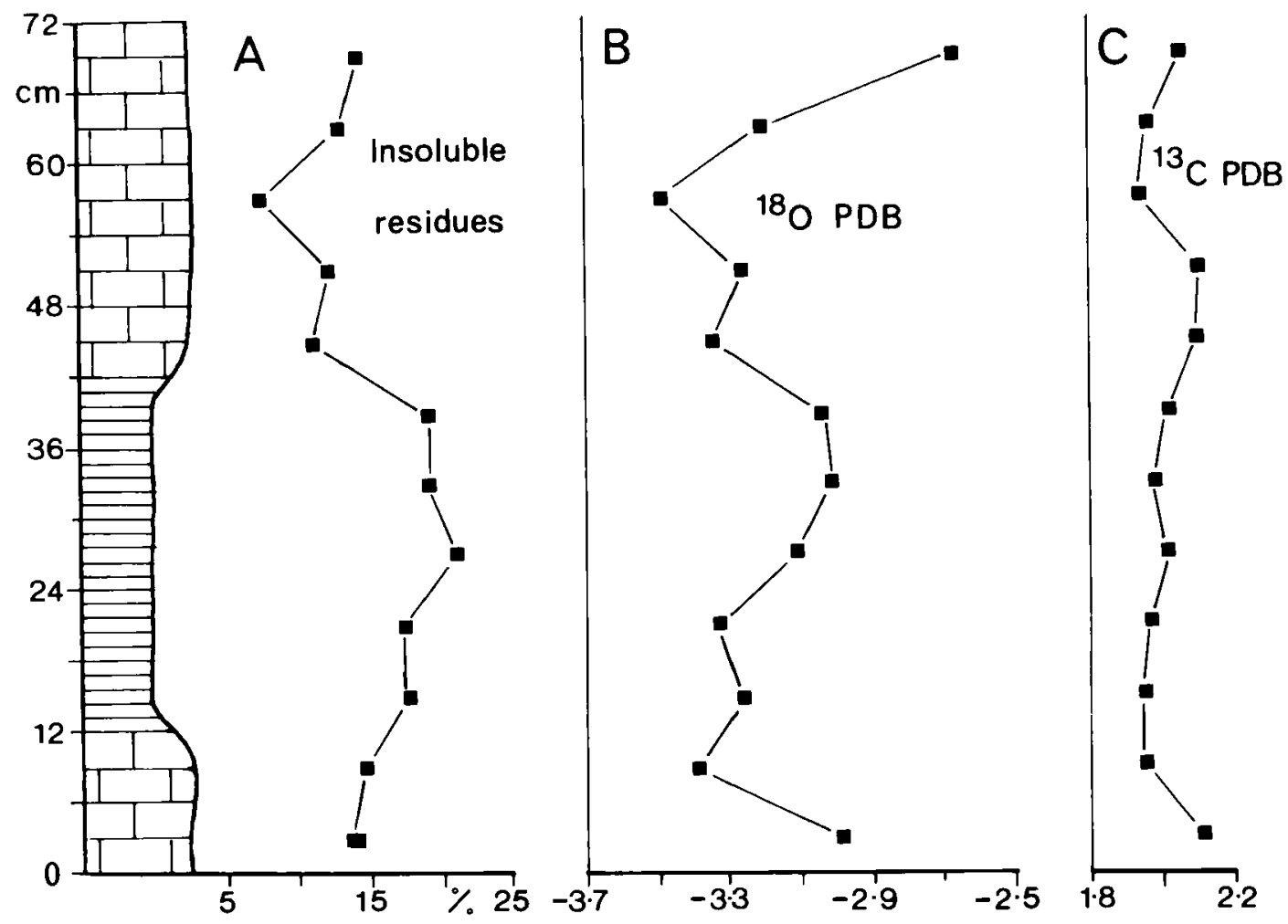

Fig. 4 Variation in (A) insoluble residues and stable isotopes of (B) oxygen and (C) carbon through a Cenomanian chalk/marl rhythm. 
b) Stable isotopes (Fig. 4B-C)

Stable isotope values were determined from bulk rock (i.e. largely coccolith debris) and therefore reflect the conditions in the top $50 \mathrm{~m}$ or so of the Cenomanian sea. Carbon stable isotope values (Fig. 4C) do not vary widely, show poor correlation with lithology and represent normal Cretaceous marine conditions. Those of oxygen vary more widely, but again do not correlate well with lithology. Both the maximum and minimum values occur within the chalks, with the marl giving intermediate values. The curve has two minima near the lithological boundaries rather than in either lithology. This is unexpected and does not closely match previous curves (Ditchfield \& Marshall, 1989, fig. 2; Ditchfield, 1990).

\section{c) Biota (Figs 5-9)}

Estimated total numbers of foraminifera show a crude mirror image of the oxygen isotope pattern in that they peak near the lithological boundaries (Fig. 5A). Figure 5B shows that this is largely due to the dominance of planktonic foraminifera. Benthonic foraminifera (Fig. 5C), both agglutinated and calcareous, show a gradual increase in abundance from the lower chalk through the marl and a similar gradual decline into the upper chalk modified by unusually low values in sample 10. Ostracods (Fig. 5D) show a third pattern that correlates poorly with lithology, but increases in variation upwards. Constituent genera of both ostracods (Fig. 9) and foraminifera (Figs 7,8) vary in abundance through the rhythm showing that some responded independently to the varying conditions.

\section{DISCUSSION OF RESULTS}

\section{a) Isotopes and insoluble residues}

Ditchfield \& Marshall (1989) demonstrated a good correlation between lithology and oxygen isotope values in Cenomanian rhythms. Oxygen isotopes are significantly lighter in the chalks than in the marls, which Ditchfield \& Marshall interpreted as due to surface waters of 'chalk' seas having been on average about $2^{\circ} \mathrm{C}$ warmer than those of 'marl' seas, with extreme values varying by about $4^{\circ} \mathrm{C}$. They concluded that the chalks were produced by increased coccolith productivity in warmer waters. Hence they interpreted the chalk/marl rhythms as productivity cylces. Earlier work on Cenomanian rhythms in Britain (Arthur et al. 1986) had suggested that these rhythms resulted from increased runoff during wetter climates causing increased clastic input to produce the marl layers, i.e. dilution cycles.

Insoluble residue data are available not only from the rhythm investigated here, but also for the original three rhythms discussed by Ditchfield \& Marshall (1989) and for an extended series of mid-Cenomanian rhythms from four localities, Cap Blanc Nez, France, Abbot's Cliff, Kent, Southerham, Sussex and Culver Cliff, Isle of Wight (Fig. 1). These can be used to investigate the consequences of the two alternative models for the generation of chalk/marl rhythms, i.e. productivity versus dilution cycles. The arguments involve a number of assumptions and the results are, therefore, tentative rather than conclusive. Nevertheless, they are instructive in clarifying depositional time limits consequent upon either model.
Productivity cycles involve the assumption that the marls represent background sedimentation and that the chalks accumulated more rapidly than the marls. Ditchfield \& Marshall (1989) demonstrated that diagenetic cements are virtually absent from, and that dissolution of original carbonate is minimal in, both lithologies. Thus if a 'clastic clock' is assumed, i.e. continuous clastic input at the same rate, then the ratio of insoluble residue contents in the chalks and marls will reflect the relative rate of their deposition. Estimated sedimentation rates can then be multiplied by bed thickness to calculate thelength of time individual beds took to accumulate. The last point assumes no differential compaction between chalk and marl beds. This is not an unwarranted assumption, although I have no quantitative data either to support or refute it. However, both the prevalence of early diagenetic cementation in carbonate sediments and the tendency of claygrade clastic sediments to dewater significantly, would suggest that if there were any difference, the marls would be more compacted than the chalks. In such a case the marls would represent even more time than is calculated here. Both differential compaction and bioturbational mixing imply that calculations of the period of chalk deposition are maxima, while those for marl deposition are minima. Finally, for these calculations I have assumed that each chalk/marl couplet represents the 21,000 year precession cycle. Calculations for dilution cycles are the same except that they assumea 'carbonate clock' and ratios of carbonate contents are used to calculate relative rates of sedimentation for the two lithologies. Results for both models are shown in Table 5 .

Despite the considerable differences in actual insoluble residue contents at the four localities with extensive data, the results assuming productivity cycles are remarkably consistent. Since these involve the same 15 rhythms, which lie between the base of the mid-Cenomanian (defined on the first appearance of the ammonite Cunningtoniceras inerme) and the mid-Cenomanian non sequence, consistent results are only likely if the initial assumptions are reasonable. These results are, therefore, more consistent with productivity cycles than with dilution cycles. Note, however, that at this stratigraphic level with either model the chalk beds represent significantly less time than the marls. Higher up the section, this is still true under the productivity model, even though the chalk beds are equally thick (the rhythm reported here) or thicker (Ditchfield \& Marshall's (1989) original three rhythms). Only under the dilution cycle model do chalks ever represent more time than marls.

\section{b) Microfauna}

The one general statement that can be made about all rhythms investigated so far is that foraminifera are significantly more abundant in the marls than in the chalks. At first this is puzzling because, if the chalk beds result from increased coccolith productivity, one might expect foraminifera to be more abundant in the chalks. However, if the chalks were deposited more rapidly than the marls this would allow a greater ratio of microfossils to sediment in the marls. It also follows that if sedimentation rate were the only contributing factor, the proportions of all microfossils would remain 


\begin{tabular}{|c|c|c|c|}
\hline $\begin{array}{l}\text { Culver Cliff ( } 16 \text { rhythms, } \\
\text { not all sampled) }\end{array}$ & Chalk & Marl & Ratio \\
\hline Mean insoluble residue (\% & $19.56(n=11)$ & $31.26(n=9)$ & $1: 1.60$ \\
\hline Mean carbonate content & 80.44 & 68.74 & $1: 1.17$ \\
\hline Total thickness (metres) & 3.00 & 3.75 & \\
\hline \multicolumn{4}{|l|}{ Estimated durations (years) } \\
\hline Productivity cycles & 7006 & 13994 & \\
\hline Dilution cycles & 10192 & 10808 & \\
\hline \multicolumn{4}{|l|}{ Southerham (15 rhythms) } \\
\hline Mean insoluble residue (\% & $11.20(n=29)$ & $19.50(n=31)$ & 1:1.74 \\
\hline Mean carbonage content & 88.80 & 80.50 & $1: 1.10$ \\
\hline Total thickness (metres) & 4.00 & 5.30 & \\
\hline \multicolumn{4}{|c|}{ Estimated durations (years) } \\
\hline Productivity cycles & 6351 & 14649 & \\
\hline Dilution cycles & 9540 & 11460 & \\
\hline \multicolumn{4}{|c|}{ Abbot's Cliff (15 rhythms) } \\
\hline Mean insoluble residue (\% & $14.71(n=29)$ & $18.96(n=60)$ & $1: 1.29$ \\
\hline Mean carbonate content & 85.29 & 81.04 & 1:1.05 \\
\hline Total thickness (metres) & 3.30 & 7.50 & \\
\hline \multicolumn{4}{|c|}{ Estimated durations (years) } \\
\hline Productivity cycles & 5344 & 15656 & \\
\hline Dilution cycles & 6647 & 14353 & \\
\hline \multicolumn{4}{|l|}{ Cap Blanc Nez (14 rhythms) } \\
\hline Mean insoluble residue (\% & $12.44(n=29)$ & $19.89(n=32)$ & $1: 1.60$ \\
\hline Mean carbonate content & 87.56 & 80.11 & $1: 1.09$ \\
\hline Total thickness (metres) & 3.90 & 6.30 & \\
\hline \multicolumn{4}{|c|}{ Estimatied durations (years) } \\
\hline Productivity cycles & 5862 & 15138 & \\
\hline Dilution cycles & 8475 & 12575 & \\
\hline
\end{tabular}

Table 5. Estimates of mean duration of deposition of chalk and marl beds in Cenomanian rhythms from four localities. (Data from Ditchfield, 1990). See text for assumptions.

constant. Total abundances of all groups would show identical patterns. Clearly this is not the case in the rhythm investigated here, where as a whole planktonic and benthonic foraminifera, and ostracods all exhibit different patterns (Fig. 5) and constituent genera of each also vary in their individual responses (Figs 7-9). However, benthonic foraminifera, whether calcareous or agglutinated, show a close correlation with insoluble residue values (Fig. 6B) which is the expected pattern of distribution if chalks were deposited more rapidly than marls. Their total abundance climbs initially to peak in the marl and declines again into the overlying chalk (Fig. 5C). If abundances of benthonic foraminifera reflect rates of sedimentation, the ratio of abundances in the chalks and marls can also be used to estimate sedimentation rates. Results are presented in Table 6. Data for absolute abundances are only available for the rhythm investigated here and for Ditchfield \& Marshall's original three rhythms. However, despite the extremely wide variation in actual abundances, in both cases the ratios are again almost identical to those for insoluble residues and therefore estimates of the duration of chalk and marl beds are very similar. I would stress that with data for only four rhythms the results should be treated with caution.
Both estimates using insoluble residues and abundances of benthonic foraminifera are consistent with the chalk/marl rhythms being productivity cycles and this idea also explains why benthonic foraminifera are more abundant in the marl beds. I assume benthonic foraminifera were passive on the sea floor and were unaffected by fluctuations in surface water temperature. Furthermore, unlike ostracods, they were unable to leave the area if sedimentation rates became uncomfortably high.

Absolute numbers of planktonic foraminifera peak near the lithological boundaries, rather than in one lithology (Fig. 5B), but show a positive correlation with surface sea water temperatures (Fig. 6A). However a different pattern occurs for the rhythms investigated by Leary et al. (1989; Fig. 10 herein). As a result, it is difficult to generalize about the response of planktonic foraminifera to changes in lithology. Nevertheless, in the rhythm investigated here estimated absolute abundances of planktonic foraminifera correlate well with surface sea water temperatures calculated from oxygen isotopes in near surface dwelling coccoliths.

Hedbergella dominates the planktonic fauna (Fig. 8, note scale is in thousands) and since it may have been the shallowestdwelling planktonic genus, this would explain why estimated total numbers of planktonic foraminifera correlate well with near-surface sea water temperatures. Rotalipora, while exhibiting a basically similar pattern, peaks at different levels, Praeglobotruncana was not present in sufficient numbers to comment on its variation. Among indidivudal genera of benthonic foraminifera, Tritaxia, the most abundant agglutinated form, and Arenobulimina exhibit the expected pattern except for an anomalously high value for Arenobulimina in sample 11 (Fig. 7). Textularia, on the other hand, is clearly more abundant in the chalks, the first definite record of a taxon being more abundant in chalk beds. Dorothia varies, seemingly randomly, while the change in Pseudotextulariella is independent of lithology. Among calcareous benthonics (Fig. 8), Gyroidinoides, Lenticulina and other nodosarians show a similar pattern to total benthonics, while Gavelinella, the most abundant calcareous form, has a distinctive trend which does

\begin{tabular}{|c|c|c|c|}
\hline & Chalk & Marl & Ratio \\
\hline \multicolumn{4}{|l|}{ Warren ( 3 rhythms) } \\
\hline Mean insoluble residues (\%) & $8.03(n=37)$ & $13.92(n=24)$ & $1: 1.73$ \\
\hline Mean total benthonic forams 22 & $1.13(n=15)$ & $384.90(n=10)$ & $1: 1.74$ \\
\hline \multicolumn{4}{|c|}{ Estimated durations (years) } \\
\hline Using insoluble residues & 9740 & 11260 & \\
\hline Using benthonic forams & 9720 & 11280 & \\
\hline \multicolumn{4}{|c|}{ (Data from Leary \& Ditchfield, 1989) } \\
\hline \multicolumn{4}{|l|}{ Abbot's Cliff (1 rhythm) } \\
\hline Mean insoluble residues (\%) & $12.4(\mathrm{n}=5)$ & $19.76(n=5)$ & $1: 1.59$ \\
\hline Mean total benthonic forams & $2486(n=5)$ & $1569(n=5)$ & $1: 1.58$ \\
\hline \multicolumn{4}{|l|}{ Estimated durations (years) } \\
\hline Using insoluble residues & 8181 & 11899 & \\
\hline $\begin{array}{l}\text { Using benthonic forams } \\
\text { (Data this paper) }\end{array}$ & 8124 & 11876 & \\
\hline
\end{tabular}

Table 6. Estimates of durations of chalk and marl beds in Cenomanian rhythms derived from insoluble residues and benthonic foraminifera. See text for assumptions. 

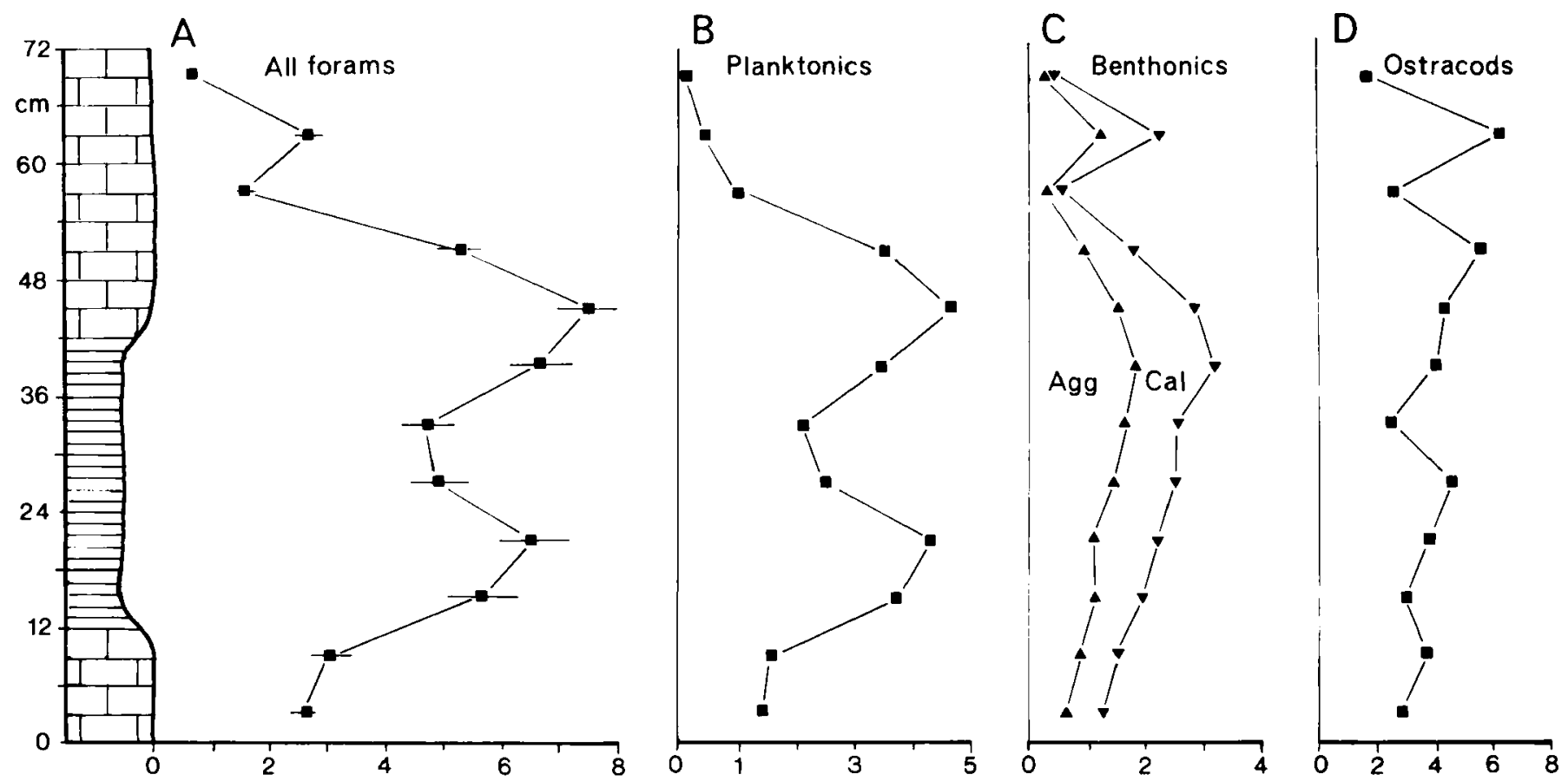

Fig. 5 Variations in microfauna through a Cenomanian chalk/marl rhythm. Scales for foraminifera in thousands, for ostracods in hundreds. All data for Figs 5-8 are estimates of absolute numbers per $100 \mathrm{~g}$ of sediment, based on counts from the $250 \mu \mathrm{m}$ size fraction only.
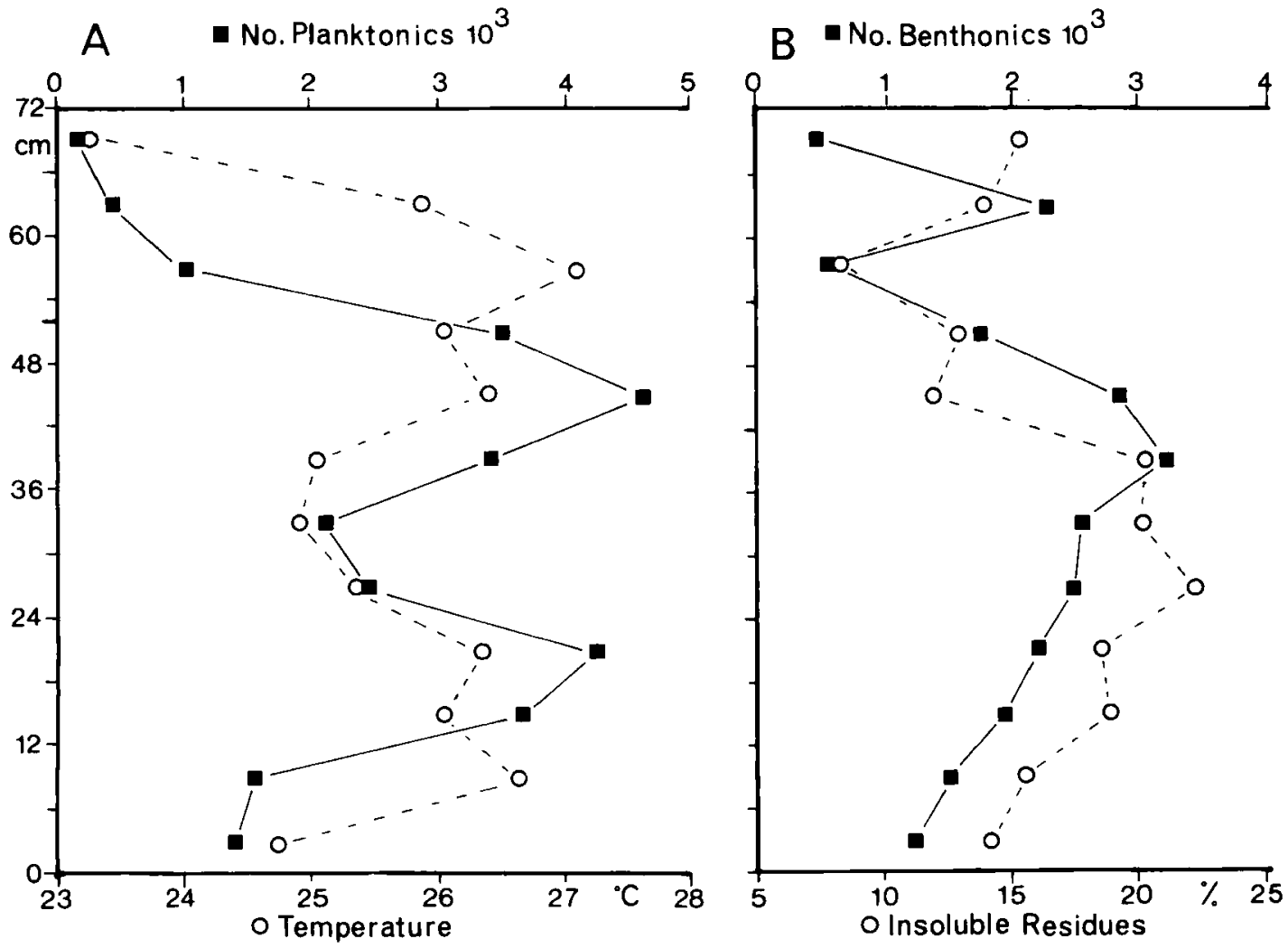

Fig. 6A, Variations through a Cenomanian chalk/marl rhythm in estimated total numbers of planktonic foraminifera per $100 \mathrm{~g}$ and surface sea water temperatures calculated from the oxygen isotope data in Fig. 4B; Fig. 6B, Variations through a Cenomanian chalk/marl rhythm in estimated total numbers of benthonic foraminifera per $100 \mathrm{~g}$ and percentage insoluble residues. Note the similarity in each pair. 

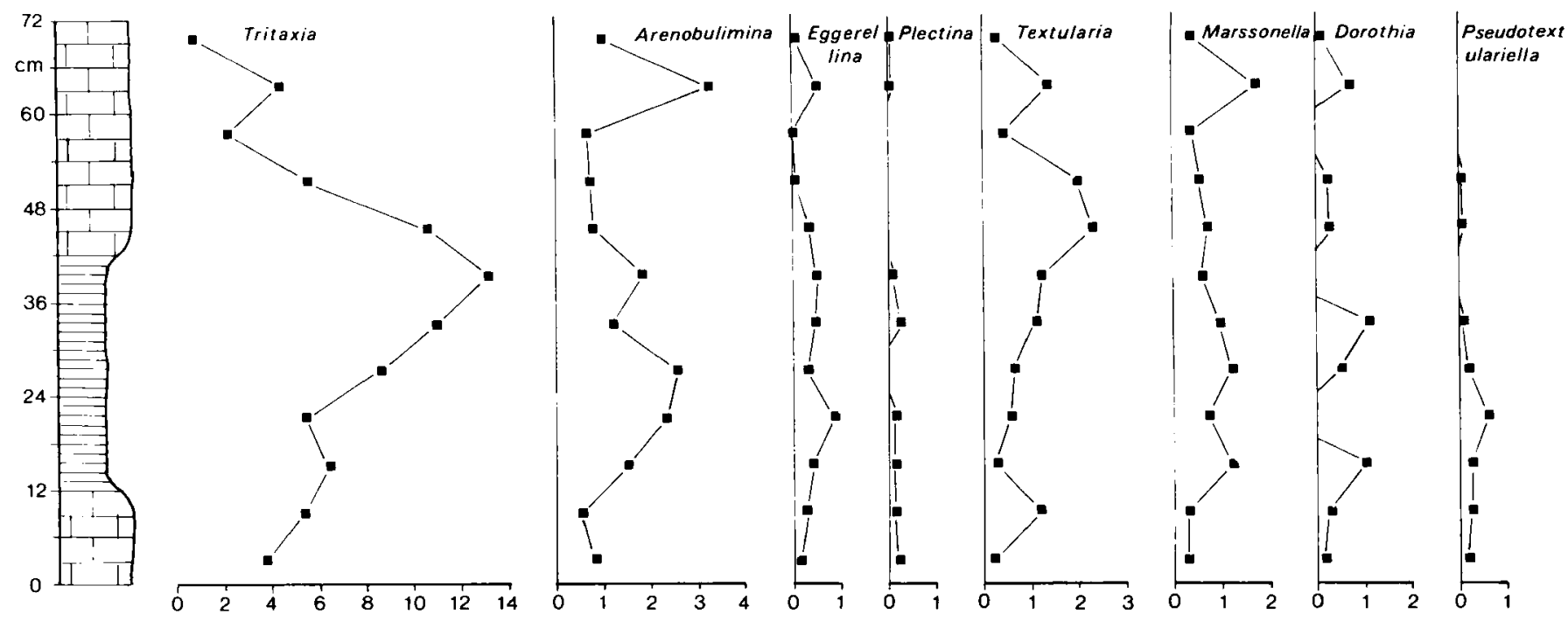

Fig. 7 Variations in abundance of selected genera of agglutinated foraminifera through a Cenomanian chalk/marl rhythm. Note the dominance of Tritaxia. All scales in hundreds.
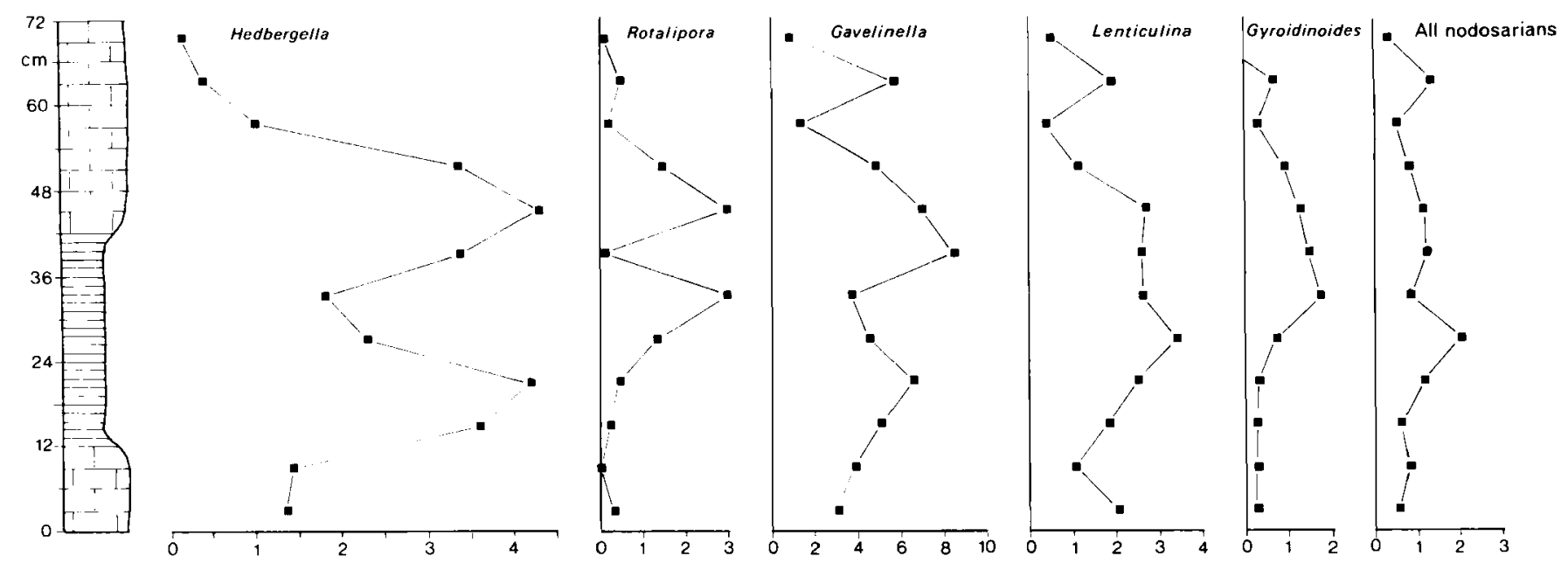

Fig. 8 Variations in abundance of selected genera of planktonic and calcareous benthonic foraminifera through a Cenomanian chalk/marl rhythm. Note dominance of Hedbergella among planktonic, and of Gavelinella among benthonic foraminifera. Scale for Hedbergella in thousands,

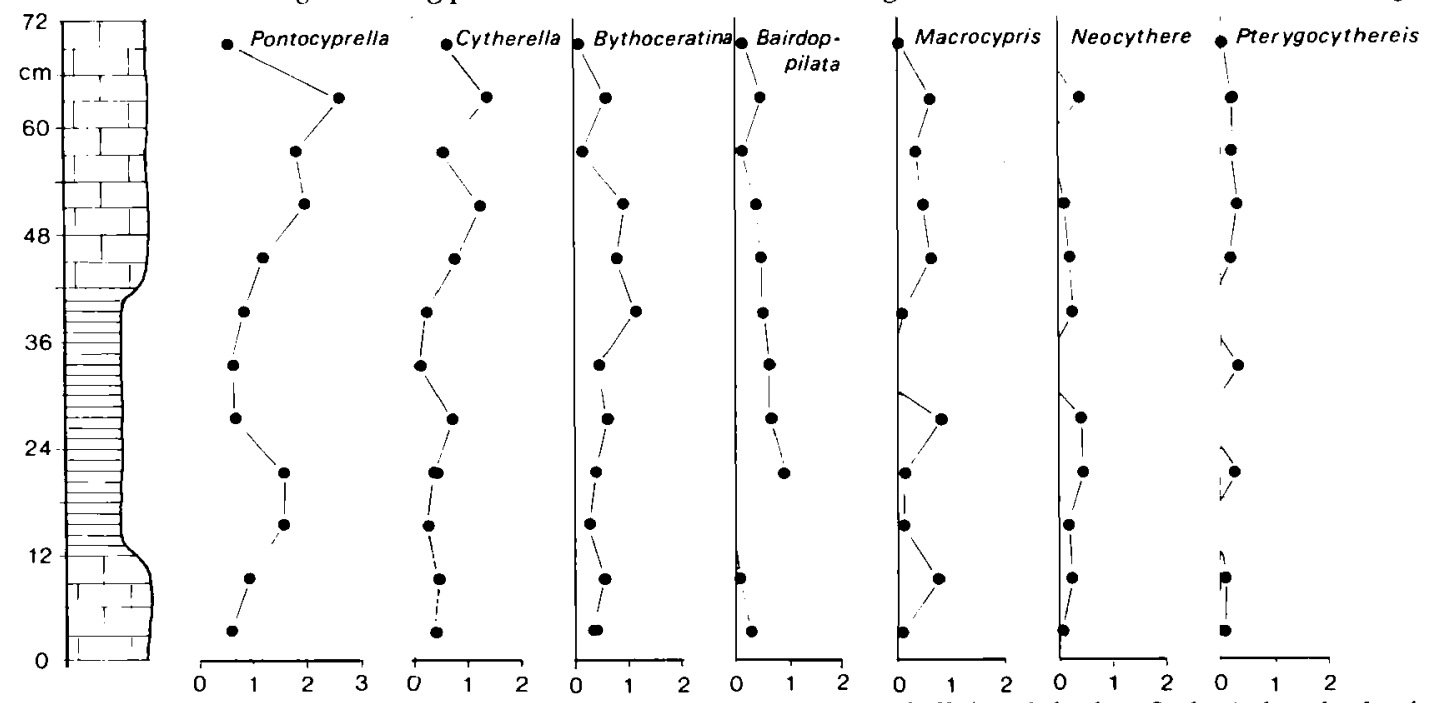

Fig. 9 Variations in abundance of selected ostracod genera through a Cenomanian chalk/marl rhythm. Scales in hundreds of valves. 
not correlate closely with lithology.

Finally, some foraminifera appear to change in response to stimuli independent of the rhythms and these may well be unique to individual rhythms. For example, in the rhythm reported here Pseudotextulariella is moderately common in the lower chalk bed and throughout the marl, but virtually disappears in the upper chalk. Lower in the sequence Tritaxia behaves in a similar manner, being common in one chalk and the base of the succeeding marl, but disappearing through the rest of the marl and well into the overlying chalk. To date too few rhythms have been investigated in detail to separate these distinctive individual responses from more general patterns. Equally, data for the Cenomanian are restricted to a few isolated rhythms, so longer period oscillations in abundance are unknown.

The ostracods as a whole present yet another pattern (Fig. 5C), which shows no strong correlation with either lithology or palaeotemperatures. Since this is the first rhythm for which data on ostracods are available, suffice it to say that overall they behave independently of either benthonic or planktonic foraminifera. Patterns for individual genera are presented in
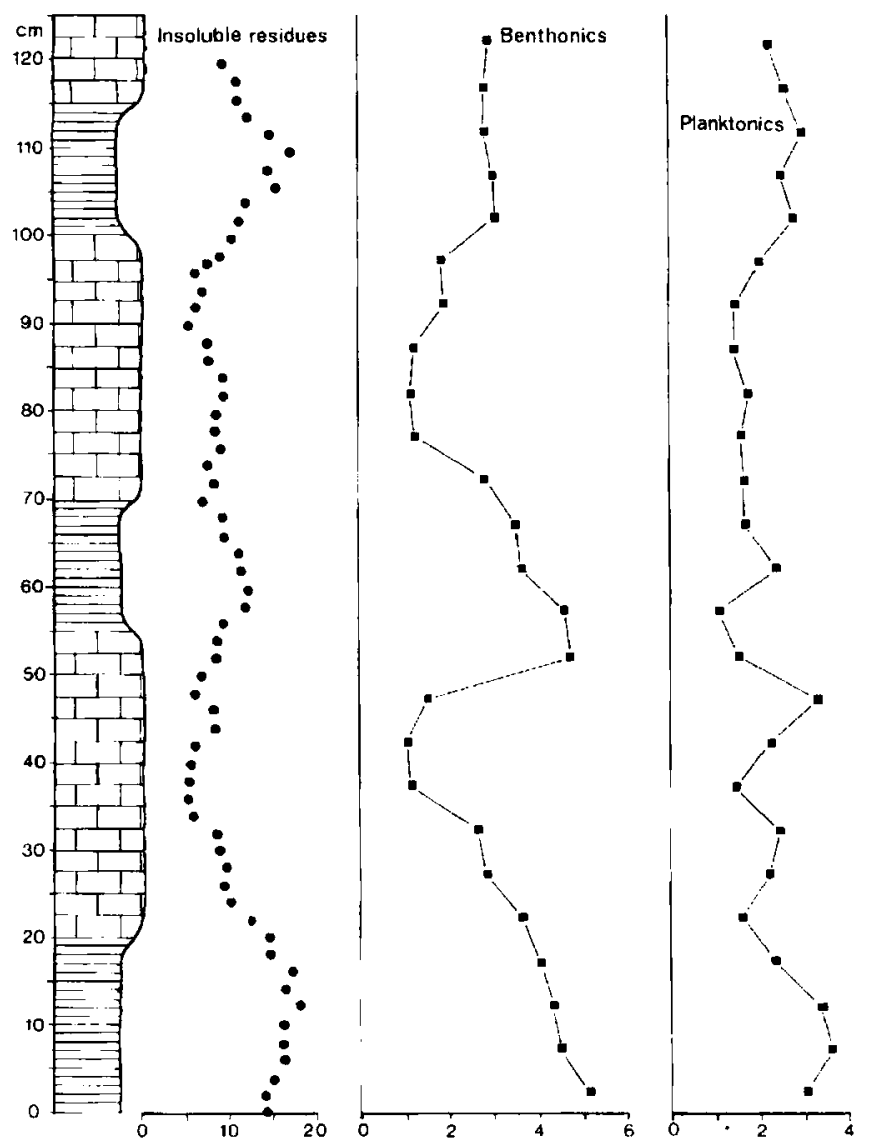

Fig. 10 Variations in (A) insoluble residues, (B) benthonic, and (C) planktonic foraminifera through three Cenomanian chalk/marl rhythms. Foraminiferal data are actual counts per $500 \mathrm{~g}$ sample based on the 500 and $250 \mu \mathrm{m}$ size fractions combined. Data supplied by $P$. Ditchfield and P.N. Leary.
Fig. 9, where the commonest genera, Pontocyprella and Cytherella show similar distributions to ostracods as a whole, and are more common in the overlying chalk. However, the rarer genera and Bythoceratina show different patterns

\section{CONCLUSIONS}

1) For quantitative data, sampling, processing and picking techniques should be standardized as far as possible, and counts made from a single size fraction of the residue.

2) However, standard counts (and percentages) are inappropriate for palaeoecological studies because a) they are interdependent so changes in the abundance of one taxon affect counts of all other taxa, b) they may give misleading results (for example where an increase in relative abundance of one taxon is accompanied by a decrease in its absolute abundance) and c) they obscure data on absolute abundance. A method of data capture that combines an adequate count with estimates of absolute abundance is recommended.

3) Percentages are appropriate to eliminate unavoidable variations in sampling and/or processing techiques.

4) If absolute abundances of microfossils are controlled by sedimentation rates this fact can be exploited to estimate sedimentation rates.

5) Planktonic and benthonic foraminifera, and ostracods all responded to changing conditions during deposition of Cenomanian chalk/marl rhythms but in different ways. Abundances of planktonic foraminifera, especially Hedbergella, seem to reflect surface sea water temperatures, those of benthonic foraminifera sedimentation rates, while ostracod abundances seem to vary independently of either control.

6) Previous oxygen isotope data (Ditchfield \& Marshall, 1989) suggest Cenomanian chalk/marl rhythms are productivity cycles with chalk beds resulting from increased coccolith production at elevated surface sea water temperatures.

7) Ratios of insoluble residues and of abundances of both agglutinated and calcareous benthonic foraminifera between chalks and marls suggest that the chalks were deposited more rapidly than the marls, taking 5-7,000 years of the 21,000 year precession cycle at most. As bioturbation has seriously mixed original sediments, estimates of the duration of chalk deposition are likely to be maxima, and are in agreement with the interpretation of the rhythms as productivity cycles. No evidence of differential compaction between chalk and marl beds has been seen, but this too would suggest estimates of the duration of chalk deposition are maxima.

8) To date microfauna of too few rhythms has been investigated to generalize about the responses of individual genera. However, since proportions of different genera vary through rhythms an element of Milankovitch control must have occurred. Equally, some rhythms show unique features which are either not orbitally induced or reflect cycles of longer period.

\section{ACKNOWLEDGEMENTS}

I am grateful to P.N. Leary for discussions and P. Ditchfield for permission to use unpublished data. Results from undergraduate projects enhanced the processing and picking techniques. Two students, John Hinchey and James Hall, collected duplicate samples which were used in this paper. 
Stable isotopes were analysed in the Liverpool University Stable Isotope Laboratory which is funded by the University and NERC research grants to J.D. Marshall. P. Ditchfield, J.D. Marshall, S. Mitchell and an anonymous reviewer suggested improvements to the manuscript, but responsibility for the ideas expressed here is the author's alone.

\section{Manuscript received August 1991 \\ Revised Manuscript accepted March 1992}

\section{REFERENCES}

Arthur, M.A. et al. 1986. Rhythmic bedding in Upper Cretaceous pelagic carbonate sequences: varying sediment response to climatic forcing. Geology, 14, 153-156.

Carter, D.J. \& Hart, M.B. 1977. Aspects of mid-Cretaceous stratigraphical micropalaeontology. Bulletin of the British Museum (Natural History), Geology Series, 29, 1-135, pls. 1-4.

Craig, H. 1957. Isotopic standards for carbon and oxygen factors for mass-spectrometric analysis of carbon dioxide. Geochimica et Cosmochimica Acta, 12, 133-149.

Croll, J. 1875. Climate and time in their geological relations. A theory of secular changes of the Earth's climate. xvi +577 pp. Daldy, Isbister \& Co., London.

Ditchfield, P.W. 1990. Milankovitch cycles in the Cenomanian chalks of the Anglo-Paris Basin. Unpublished Ph.D thesis, University of Liverpool.

Ditchfield,P.W.\& Marshall,J.D. 1989. Isotopic variation in rhythmically bedded chalks: palaeotemperature variation in the Upper Cretaceous. Geology, 17, 841-845.

Friedman, I. \& O'Neil, J.R. 1977. Compilation of stable isotope fractionation factors of geochemical interest. In: Fleischer, M. (ed.) Data of Geochemistry. U.S. Geological Survey Professional Paper, 440.KK.
Gilbert, G.K. 1895. Sedimentary measurement of geologic time. J. Geol., 3, 1231-127.

Hay, W.W. 1972. Probabilistic stratigraphy. Eclog. geol. Helv., 65, 255266.

Jukes-Browne, A.J. \& Hill, W. 1903. The Cretaceous rocks of Britain. Vol. 2, The Lower and Middle Chalk of England. Mem. Geol. Surv. U.K. xiii + 568pp.

Leary, P.N., Cottle, R. \& Ditchfield, P.W. 1989. Milankovitch control of foraminiferal assemblages from the Cenomanian of southern England. Terra nova, 1, 416-419.

Leary, P.N. \& Ditchfield, P.W. 1989. The foraminiferal assemblage against the oxygen isotope signature through three Cenomanian (Cretaceous) marl chalk-marl rhythms from S.E. England. Mesozoic Res., 2, 75-81.

Mosimann, J.E. 1965. Statistical methods for the pollen analyst: multinomial and negative multinomial techniques. In: Kummel, B. \& Raup, D. (eds) Handbook of paleontological techniques, 636-673, Freeman, San Francisco.

Murray,J.W. 1973. Distribution and ecology of living benthic Foraminiferida, 274pp., Heinemann, London.

Paul, C.R.C. 1982. The adequacy of the fossil record. In: Joysey, K.A. \& Friday, A.E. (eds) Problems of phylogenetic reconstruction, 75-117, Academic Press, London.

Raup, D.M. 1975. Taxonomic diversity estimation using rarefaction. Paleobiology, 1, 333-342.

Shackleton, N.J. \& Opdyke, N. 1973. Oxygen isotopic and palaeomagnetic stratigraphy of equatorial Pacific core V28-238: oxygen isotope temperatures and ice volumes on a 100,000 year time scale. Quat. Geol., 3, 39-55.

Shaw, A.B. 1964. Time in stratigraphy, 365pp, McGraw Hill, New York. 